\title{
Modelling of Photovoltaic Solar Panel for Maximum Power Point Tracking
}

\author{
Ankita Pandey ${ }^{1}$, Dr. Dharmendra Kumar Singh ${ }^{2}$
}

\begin{abstract}
In recent year, the use of solar energy has become an alternative source of energy of great importance. Several research and efforts have been concentrated on the important of the efficiency of photovoltaic system and in the accessibility to this technology. Photovoltaic power generation system implements an effective utilization of solar energy but generally has very low conversion efficiency. Maximum power point tracking (MPPT) is used in photovoltaic (PV) system to maximize the photovoltaic array output power, irrespective of the temperature and irradiation condition and of the load electrical characteristics. In this paper we study and present the matlab simulation of $P V$ panel for maximum power point tracking.
\end{abstract}

Keyword: Photovoltaic system, maximum power point tracking, PV cell, renewable energy

\section{Introduction}

In recent decades, researches on the use of solar energy as an alternative source of energy have become a role of prominence in the field of electrical engineering. In parallel, new materials for the manufacture of photovoltaic panels and new methods of control are being developed to reduce costs and increase the efficiency of power converters. Among these techniques, a great effort has been spent with the algorithms for the maximum power tracking (MPPT) considering the variations of parameters such as temperature, solar irradiation or the load of the system [1].

Solar energy is one of the most important renewable energy sources that have been gaining increased attention in recent years. Solar energy is plentiful; it has the greatest availability compared to other energy sources. The amount of energy supplied to the earth in one day by the sun is sufficient to power the total energy needs of the earth for one year. Solar energy is clean and free of emissions, since it does not produce pollutants or by-products harmful to nature. The conversion of solar energy into electrical energy has many application fields. Recently, research and development of low cost flat-panel solar panels, thin-film devices, concentrator systems, and many innovative concepts have increased. In the near future, the costs of small solar-power modular units and solar-power plants will be economically feasible for large-scale production and use of solar energy[2]. The PV energy is produced by panels and PV systems. These last ones suffer from a lack of optimization and the divergence after sudden variations of the illumination and the load [3].

In high power applications, the cost of MPPT control is low as against the cost of the photovoltaic (PV) array and power converters. However, for low power applications, the implementation cost of an MPPT algorithm is a concern. The most commonly used hill-climbing MPPT technique is the $\mathrm{P} \& \mathrm{O}$ algorithm [4].

\section{Principle of Operation and Equivalent Circuit}

The operation of solar cell is similar to PN junction where there are diffusion current and dirft currents for direct and reverse polarization. A solar panel cell basically is a p-n semiconductor junction. When exposed to the light, a DC current is generated. The generated current varies linearly with the solar irradiance. The equivalent electrical circuit of an ideal solar cell can be treated as a current source parallel with a diode shown in figure 1[5].

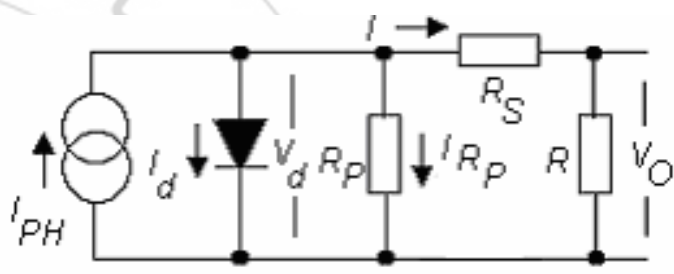

Figure 1: Equivalent Circuit of solar cell

PV cells are grouped in larger units called Modules, which are further interconnected in a series-parallel configuration to form PV array. The following are the basic equations from the theory of semiconductors and Photovoltaic that mathematically describes the I-V characteristic of the photovoltaic cell and Module[6].

In PV module number of solar cells connected in series $(\mathrm{Ns}=36)$ and parallel $(\mathrm{Np}=1)$ for obtaining the desired voltage and current output levels. Each solar cell is basically a p-n diode. As sunlight strikes a solar cell, the incident energy is converted directly into electrical energy without any mechanical effort[6].

From Fig. 1 shows the equivalent circuit of the solar cell, formed by a current source Iph in anti-parallel with diode driven by a current Id. The diode determines the currentvoltage output characteristic (IxV) and includes the voltage and current dependence of the cell in relation to the temperature. Based on this complete equivalent circuit, the output current of the solar cell can be calculated as,

$$
\mathrm{I}=\mathrm{I}_{\mathrm{ph}}-\mathrm{I}_{\mathrm{d}}-\mathrm{I}_{\mathrm{Rp}}
$$

where Iph is the current generated by irradiation also called short-circuit current, $I_{d}$ and $I_{R p}$ represent the diffusion current of the internal diode and the loss of current in $\mathrm{Rp}$.

Considering the characteristic IxV the PN junction, the output current of the cell can be rewritten of the way: 


\section{International Journal of Science and Research (IJSR) \\ ISSN (Online): 2319-7064}

Index Copernicus Value (2013): 6.14 | Impact Factor (2015): 6.391

$$
I=I_{p h}-I_{0}\left(e^{\frac{q\left(V_{o+I R S}\right)}{A K T}}-1\right)-\frac{V o+I R s}{R p}
$$

where I and Vo are, respectively, the output current and voltage of the solar cell. Io is the reverse saturation current of the diode, $q$ is the charge of the electron, $A$ is the diode ideality factor, $K$ is the Boltzmann constant, $T$ is the temperature in ${ }^{\circ} K, R s$ and $R p$ represent the internal series and parallel resistances, respectively.

In the region of low voltage where the current through the greater influence. This resistance is mainly due to the leakage of current in the cell surface, acting significantly only when the cells are in low brightness. The series resistance has origin in the metallic contacts and it offers significant influence on the performance of the solar cell. equivalent circuit is very small, the parallel resistance has

\section{MATLAB Simulation Model, I-V and P-V Curve}

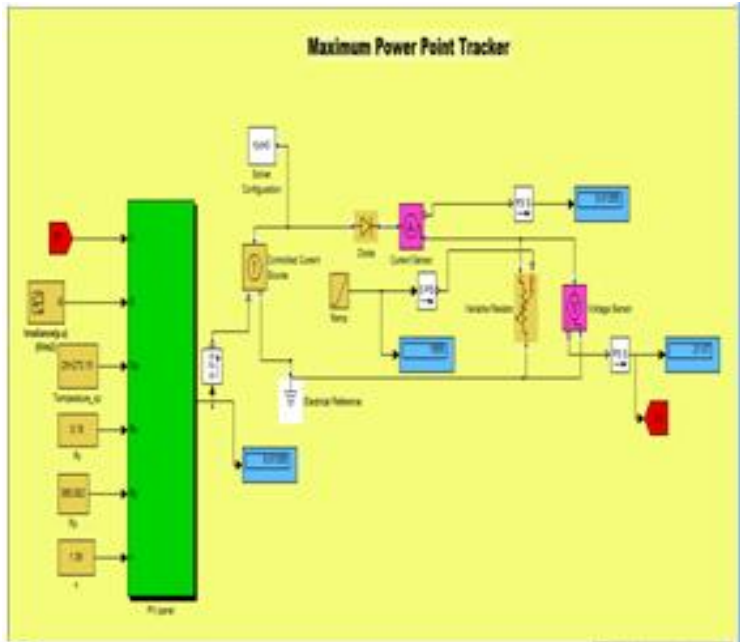

Figure 4: Simulation model of PV panel for MPPT

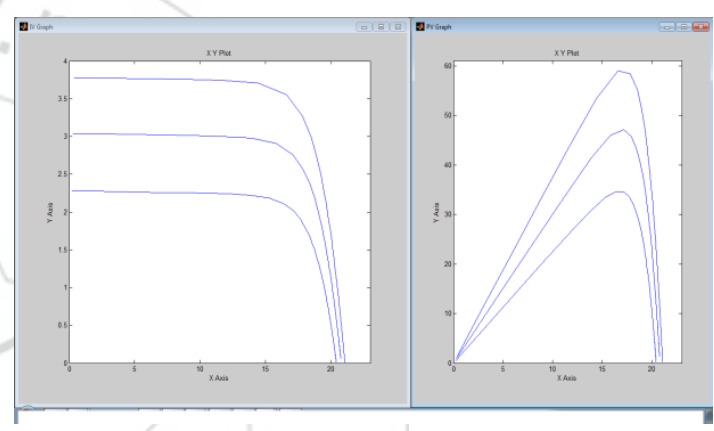

Figure 5: At temperature $25 o_{C}$

Where $\mathrm{V}=\frac{\mathrm{KT}}{\mathrm{q}}$ (thermal voltage), the equation of the output voltage of the cell will be given:

$$
\mathrm{Vo}=-\mathrm{IRs}+\frac{\mathrm{AKT}}{\mathrm{q}} \ln \left(\frac{\mathrm{Iph}-\mathrm{I}-\mathrm{Io}}{\mathrm{Io}}\right)
$$

The output power of the solar cell is calculated as:

$$
\mathrm{Po}=\mathrm{IVO}
$$

\section{Dependency with Temperature and Solar Irradiation}

From equation (1) to (4) it is clear that a high dependence of the output current of the cell in relation to the temperature and solar irradiation. The output power of the cell is totally dependent on the climate condition in which it is placed.

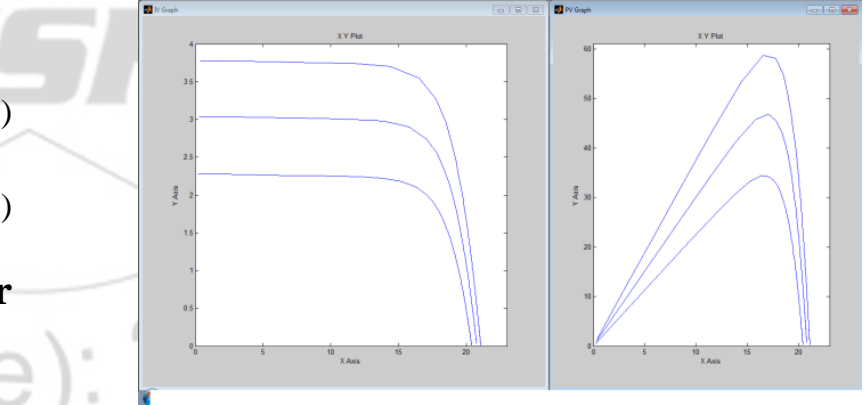

Figure 6: At temperature $35 o_{C}$

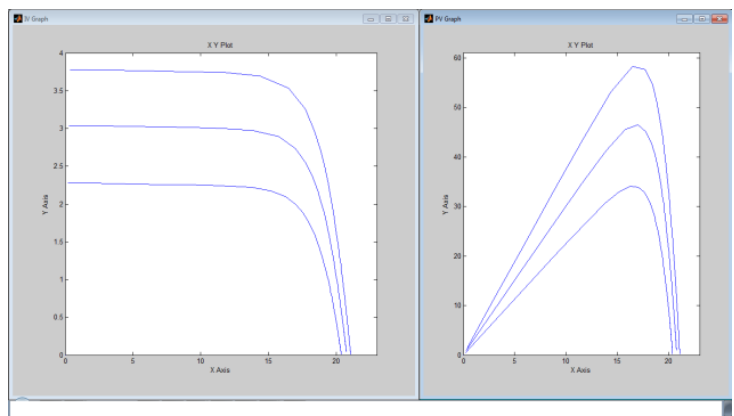

Figure 7: At temperature $45 o_{C}$

The above fig.5, 6, 7 shows the I-V and P-V curve for different voltage. 


\section{International Journal of Science and Research (IJSR) \\ ISSN (Online): 2319-7064}

Index Copernicus Value (2013): 6.14 | Impact Factor (2015): 6.391

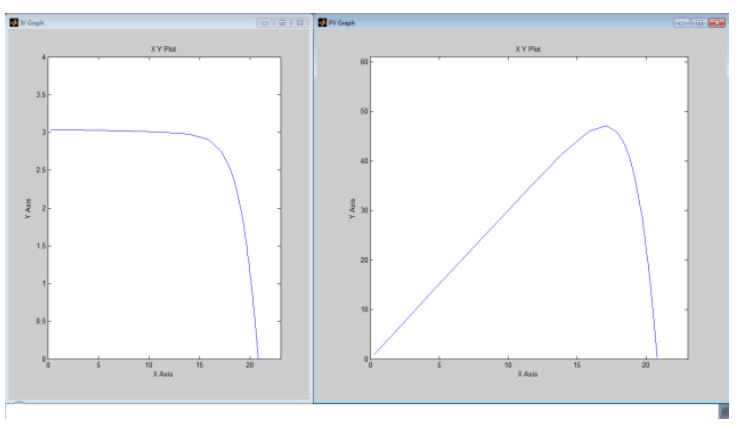

Figure 8: At load $0.1 \mathrm{ohm}$

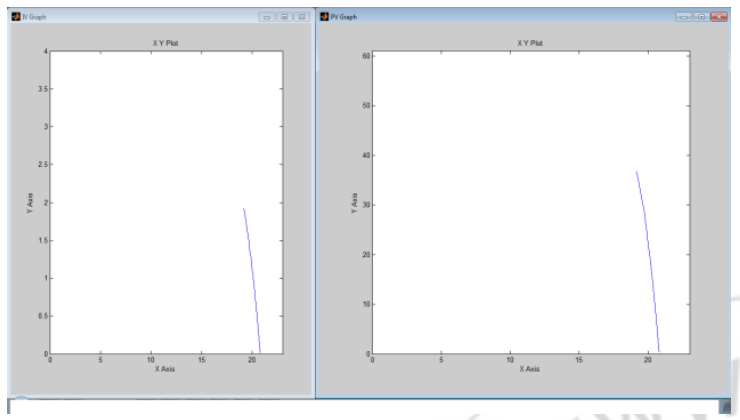

Figure 9: At load $10 \mathrm{ohm}$

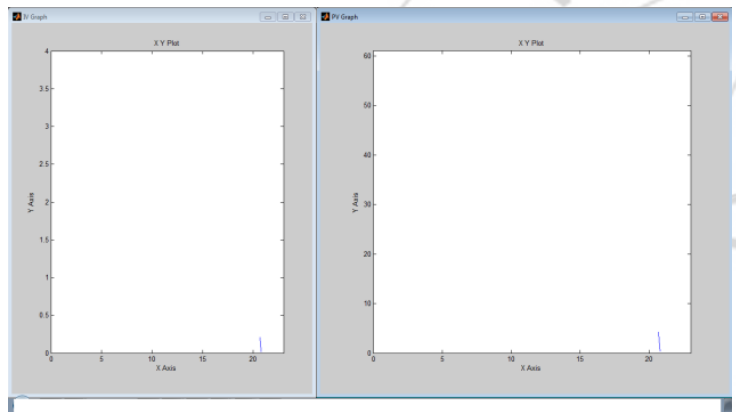

Figure 10: At load $100 \mathrm{ohm}$

[3] E. Baghaz, M. Melhaoui, M. F. Yaden and K. Kassmi "Photovoltaic System Equipped with a DC/DC Buck Converter and a MPPT Command Ensuring an Optimal Functioning Independently of System Perturbations" Physical Review \& Research International4(1): 80-99, 2014

[4] Dhananjay Choudhary, Anmol Ratna Saxena “ DC-DC Converter for MPPT of P-V System" International Journal of Emerging Technology and Advanced Engineering, Volume 4, Issue 7, July 2014

[5] A.Pradeep Kumar Yadav, S.Thirumaliah, G.Haritha "Comparison of MPPT Algorithms for DC-DC Converters Based PV Systems" International Journal of Advanced Research in Electrical, Electronics and Instrumentation Engineering Vol. 1, Issue 1, July 2012

[6] D.Shankar, and P.S.Kulkarni "Soft Switching Buck Converter for Battery Charging With MPPT" International Journal of ChemTech Research, Vol.5, No.2, pp 947-956, April-June 2013

\section{Author Profile}

Ankita Pandey is pursuing M.Tech (Power System) from Dr. C.V Raman University Bilaspur. She has completed B.E. (Electrical Engineering) From C.S.V.T.U. Bhilai (C.G.), India

Dr. Dharmendra Kumar Singh is H.O.D. Electrical and Electronics department, Dr. C.V. Raman University, bilaspure. Recently he has done his Phd from Dr. C.V.Raman university bilaspure (C.G.), India

\section{Conclusion}

In this paper we study the basics, principle of operation of maximum power point tracking and present the simulation model of PV panel for maximum power point tracking. The maximum power point tracking (MPPT) is a technique used with wind turbine and photovoltaic (PV) solar systems to maximize power output. The solar cells have a complex relationship between temperature and total resistance that produces a non-linear output efficiency which can be analyzed based on I-V curve.

\section{References}

[1] P. C. M. Bernardo, Z. M. A. Peixoto and L.V. B. Machado Neto "A High Efficient Micro-controlled Buck Converter with Maximum Power Point Tracking for Photovoltaic Systems" International Conference on Renewable Energies and Power Quality (ICREPQ'09) Valencia (Spain), 15th to 17th April, 2009

[2] Dr. Anil S. Hiwale, Mugdha V.Patil2,Hemangi Vinchurkar "An Efficient MPPT Solar Charge Controller" International Journal of Advanced Research in Electrical, Electronics and Instrumentation Engineering, Vol. 3, Issue 7, July 2014 